\title{
Pemberdayaan Masyarakat Melalui Corporate Social Responsibility (CSR) dalam Pengendalian Penyakit Tidak Menular (Studi Agen Perubahan di Kecamatan Cicurug, Kabupaten Sukabumi)
}

\author{
Community Empowerment through Corporate Social Responsibility (CSR) in Control of Non- \\ Communicable Disease (Study Agent for Change in Cicurug Sub-district, Sukabumi District)
}

\author{
Rustika*, Noor Edi Widya Sukoco, dan Tety Rachmawati \\ Pusat Humaniora Kebijakan Kesehatan dan Pemberdayaan Masyarakat, Badan Litbangkes, Kementerian \\ Kesehatan RI, J1. Percetakan Negara No. 23, Kotak Pos 1226 Jakarta, Indonesia \\ *Korespondensi Penulis: rustikaherman@yahoo.co.id
}

Submitted: 22-02-2018, Revised: 04-05-2018, Accepted: 29-05-2018

DOI: http://dx.doi.org/10.22435/mpk.v28i2.179

\begin{abstract}
Abstrak
Jumlah kasus hipertensi di Puskesmas Cicurug Kabupaten Sukabumi sebesar 40\%, dengan faktor risiko yang terlaporkan kebiasaan merokok, perilaku hidup bersih dan sehat (PHBS) sebesar $70 \%$. Pengendalian penyakit tidak menular dilakukan melalui pemberdayaan masyarakat dengan pemicuan agen perubahan (agent of change). Tujuan penelitian untuk menerapkan program pemberdayaan masyarakat dalam pengendalian penyakit tidak menular berbasis masyarakat (P2TMBM) melalui agen perubahan.Kegiatan tersebut terselenggara atas dukungan Corporate Social Responsibility (CSR) yang ada di Kabupaten Sukabumi. Penelitian ini merupakan riset operasional yang menggunakan metode Quasi Eksperimental dengan desain Participatory Rural Appraisal (PRA) yaitu metode survei untuk menentukan potensi pemberdayaan masyarakat di bidang kesehatan dengan penggalian berbagai informasi tentang Upaya Kesehatan Berbasis Masyarakat (UKBM), dilakukan dengan teknik pemicuan terhadap agen perubahan (agent of change). Tempat kegiatan di Desa Nyangkowek (intervensi pemicuan P2TMBM) dan Desa Purwasari (kontrol metode lama). Penelitian ini dilakukan di bulan Februari - Oktober 2015. Sampel adalah 40 agen perubahan yang terdiri dari 20 orang desa intervensi dan 20 orang desa kontrol. Variabel adalah umur, jenis kelamin, pekerjaan, pengetahuan, sikap, dan perilaku faktor risiko penyakit tidak menular (merokok, pola makan, dan aktivitas fisik). Cara pengumpulan data dengan wawancara mendalam dan observasi. Hasil penelitian menunjukkan bahwa Pemicuan pada AOC telah berhasil meningkatkan secara signifikan $(p<0,05)$ pengetahuan, sikap dan perilaku agent of change dalam pengendalian penyakit tidak menular. Program CSR Aqua Lestari di Kecamatan Cicurug Kabupaten Sukabumi mampu menjaga keberlangsungan pemberdayaan masyarakat dalam pengendalian faktor risiko PTM
\end{abstract}

Kata Kunci: pemberdayaan masyarakat, agen perubahan, CSR

\begin{abstract}
The number of cases of hypertension in Cicurug, Health Center of Sukabumi District West Java amounted to $40 \%$, with risk factors reported smoking habit, clean, and healthy behavior (PHBS) of $70 \%$. Non communicable diseases control is done through community empowerment with agent of change (AoC) triggering. The purpose of the research is to implement community empowerment program in communitybased non comunicable disease control (P2PTM) through the change agent. The activity is held by Corporate Social Responsibility (CSR) support in Sukabumi District. This research is an operational research using Quasi Experimental method with Participatory Rural Appraisal (PRA) design that is survey method to determine the potential of community empowerment in health by extracting various information
\end{abstract}


about Community Based Health Effort (UKBM), done by triggering technique to change agent (agent of change). Place of activity in Nyangkowek Village (P2TMBM triggering intervention) and Purwasari Village (old method control). This research was conducted in February-October, 2015. The sample is 40 change agents consisting 20 villagers and 20 control villages. Variables are age, sex, occupation, knowledge, attitude and behavior of non-communicable disease (PTM) risk factors (smoking, diet and physical activity). How to collect data with in-depth interviews and observation. The results of the study indicate that triggers in AoC have significantly increased $(p<0.05)$ on knowledge, attitude and behavior of Agent of Change in non-communicable disease control. CSR program named "Aqua Lestari" in Cicurug Sub-Sukabumi District is able to maintain the continuity of community empowerment in controlling not communicable desease (PTM) risk factors.

Keywords : community empowerment, agent of change, CSR.

\section{PENDAHULUAN}

Proporsi penyakit tidak menular diabetes melitus (DM), hipertensi dan penyakit jantung koroner (PJK) di Indonesia meningkat. Data Riset Kesehatan Dasar (Riskesdas) tahun 2007 dan 2013 menunjukkan bahwa jumlah penderita (berdasarkan diagnosis tenaga kesehatan) terhadap populasi usia di atas 15 tahun dalam 12 bulan terakhir adalah penyakit DM meningkat dari $0,7 \%$ menjadi $1,5 \%$; hipertensi dari $7,2 \%$ menjadi $9,4 \%$; dan stroke dari $8,3 \%$ menjadi $12,1 \% .{ }^{1,2}$ Faktor risiko penyakit tidak menular (PTM) yang ditunjukkan dari perilaku adalah kebiasaan merokok setiap hari usia $\geq 10$ tahun, kurang aktivitas fisik, perilaku makanan berlemak, kolesterol dan makanan gorengan $\geq 1$ kali per hari; obesitas sentral dan hipertensi. Riskesdas tahun 2013 menunjukkan bahwa kebiasaan merokok setiap hari usia $\geq 10$ tahun sebesar $24,3 \%$; kurang aktivitas fisik sebesar 26,1\%; perilaku makanan berlemak, kolesterol dan makanan gorengan $\geq$ 1 kali per hari sebesar sebesar $40,7 \%$; obesitas sentral sebesar $26,6 \%{ }^{2}$

Data diabetes, hipertensi, dan PJK di Jawa Barat pada tahun 2013 menunjukkan diabetes sebesar 1,3\%; hipertensi sebesar 10,6\%; PJK sebesar 0,5\%; dan stroke sebesar 12 permil. Sedangkan faktor risiko PTM di Jawa Barat menunjukkan persentase kebiasaan merokok setiap hari usia $\geq 10$ tahun sebesar $27,1 \%$; kurang aktivitas fisik sebesar 25,4\%; kurang makan buah dan sayur sebesar $96,5 \%$; perilaku mengonsumsi makanan berlemak, kolesterol dan makanan gorengan $\geq 1$ kali per hari sebesar 50,1\%. ${ }^{2}$ Data PTM di Kabupaten Sukabumi menunjukkan diabetes sebesar 1\%; hipertensi sebesar 11,5\%; PJK sebesar 1,4\%; dan stroke sebesar 7 permil. Faktor risiko PTM di Kabupaten Sukabumi menunjukkan persentase kebiasaan merokok setiap hari usia $\geq 10$ tahun sebesar 29,1\%; kurang aktivitas fisik sebesar $6,3 \%$, perilaku mengonsumsi makanan berlemak, kolesterol, dan makanan gorengan $\geq 1$ kali per hari sebesar 34,3\%. ${ }^{2}$ Puskesmas Cicurug sebagai lokasi penelitian diperoleh data kunjungan pasien yaitu hipertensi sebesar 40\%, PHBS mencapai $70 \%$, variabel faktor risiko PTM yang diketahui adalah merokok. ${ }^{3}$ Faktor risiko PTM lainnya belum tersedia hal ini menjadikan kendala dalam melakukan intervensi kedepannya.

Pemberdayaan masyarakat di bidang kesehatan telah dijamin dalam Undang-Undang Kesehatan No. 36 Tahun 2009. Pasal 174 mengamanatkan bahwa masyarakat berperan serta baik secara perseorangan maupun terorganisasi dalam segala bentuk dan tahapan pembangunan kesehatan untuk mempercepat pencapaian derajat kesehatan masyarakat setinggi-tingginya. ${ }^{4}$ Pemberdayaan masyarakat adalah segala upaya memberi kekuatan kepada pihak yang kurang atau tidak berdaya agar dapat memiliki kekuatan yang menjadi modal dasar aktualisasi diri. ${ }^{5}$ Pemberdayaan masyarakat yang dilakukan meliputi peningkatan pengetahuan dan kemampuan masyarakat agar mampu mengidentifikasi masalah, merencanakan, dan melakukan pemecahannya dengan memanfaatkan potensi dan fasilitas yang ada, baik dari lintas sektor maupun lembaga swadaya masyarakat (LSM) dan tokoh masyarakat. ${ }^{6}$ Sumber dana yang digunakan untuk pemberdayaan masyarakat berasal dari Anggaran Pendapatan dan Belanja Negara (APBN), Anggaran Pendapatan dan Belanja Daerah (APBD) maupun dana dari swasta dalam bentuk Corporate Social Responsibility (CSR).

CSR merupakan komitmen perusahaan untuk melaksanakan kewajibannya didasarkan atas keputusan untuk mengambil kebijakan dan 
tindakan dengan memperhatikan kepentingan stakeholders dan lingkungan dimana perusahaan melakukan aktivitas berlandaskan pada ketentuan hukum yang berlaku. Beberapa program CSR untuk kesehatan antara lain pengembangan makanan sehat dan organik, pemberdayaan masyarakat untuk perbaikan sanitasi lingkungan, kampanye lingkungan, dan perilaku sehat. ${ }^{7}$ Perusahaan yang telah meyakini CSR sebagai suatu kewajiban maka dengan sendirinya perusahaan tersebut telah melaksanakan investasi sosial. Sebagai investasi sosial maka perusahaan akan memperoleh keuntungan dalam bentuk manfaat yaitu mempertinggi reputasi dan corporate building serta menurunkan kerentanan gejolak dengan komunitas. ${ }^{8}$

Pengendalian PTM di Kabupaten Sukabumi yang telah dilakukan berdasar Peraturan Bupati No. 26 tahun 2011 adalah kawasan bebas asap rokok. Namun implementasi peraturan tersebut belum maksimal. Program pos pembinaan terpadu (posbindu) PTM dan posbindu lansia belum berjalan dengan baik. Sarana dan prasarana skrining PTM (Posbindu Kit) masih terbatas. Kecamatan Cicurug dipilih sebagai daerah penelitian dengan pertimbangan terdapat sekitar 120 perusahaan yang potensial memberikan CSR, tingginya perokok aktif, pola konsumsi makanan gorengan dan makanan instan serta daerah yang sedang berkembang sebagai penyangga ibu kota negara (Jakarta). Sumber daya manusia masyarakat lokal dan pendatang banyak sebagai buruh pabrik dengan Upah Minimum Regional (UMR) yang rendah sebesar Rp. 1.200.000,- per bulan. ${ }^{3}$

Kepala desa sangat mendukung pengendalian PTM dalam mengantisipasi bahaya yang ditimbulkan dari perilaku pola makanan yang biasa dikonsumsi. Pemberdayaan masyarakat yang dilakukan melalui pengembangan potensi masyarakat dalam upaya pengendalian perilaku faktor risiko penyakit tidak menular yaitu hipertensi, stroke, DM, dan PJK secara mandiri. CSR yang ada di Kabupaten Sukabumi mendukung pemberdayaan masyarakat dalam bentuk pembangunan posbindu lansia dan keberlangsungan pengendalian faktor risiko PTM yaitu aktivitas fisik, penyuluhan dan pemeriksaan kesehatan. Penelitian ini merupakan bagian dari penelitian pemicuan pencegahan penyakit tidak menular berbasis masyarakat di Indonesia, ${ }^{9}$ sehingga tujuan penelitian ini adalah menggali informasi tentang potensi masyarakat dalam rangka pengembangan kegiatan pemberdayaan masyarakat di bidang pengendalian PTM serta peran CSR di Desa Nyangkowek dan Desa Puwosari, Kecamatan Cicurug, di Kabupaten Sukabumi.

\section{METODE}

Jenis penelitian ini merupakan riset operasional yang menggunakan metode Quasi Experimental dengan pendekatan Participatory Rural Appraisal (PRA) yaitu metode survei untuk menentukan potensi pemberdayaan masyarakat di bidang kesehatan dengan penggalian berbagai informasi tentang Upaya Kesehatan Berbasis Masyarakat (UKBM). Pelaksanaan pemberdayaan masyarakat melalui proses pemicuan dengan penerapan model Pengendalian Penyakit Tidak Menular Berbasis Masyarakat (P2TMBM) mulai dari membangun komitmen sampai dengan melakukan monitoring dan evaluasi. ${ }^{10}$

Responden pemberdayaan yaitu Agen Perubahan (Agent of Change/AoC) yang terdiri dari anggota rumah tangga, kader, organisasi masyarakat/Lembaga Swadaya Masyarakat (LSM), guru, dan aparat desa yang akan dijadikan motor penggerak masyarakat dalam upaya pengendalian PTM di Kecamatan Cicurug. Lokasi penelitian di dua desa yaitu Desa Nyangkowek sebagai daerah intervensi dan Desa Purwosari sebagai daerah kontrol. Setiap desa diambil 20 orang agen perubahan.

Proses pemberdayaan pada agen perubahan di daerah intervensi, dimulai dengan pemberian materi pemicuan meliputi pengetahuan, sikap, dan perilaku berisiko PTM yaitu perilaku merokok, pola makan tidak sehat, kurangnya aktifitas fisik serta dampak yang ditimbulkan akibat faktor risiko dari PTM yaitu penyakit hipertensi, stroke, jantung, dan DM. Pemicuan diberikan selama 3 hari berturut-turut $( \pm 3-4$ jam per hari) oleh tim peneliti dan tim puskesmas. Desa kontrol diberikan penyuluhan faktor risiko PTM selama tiga hari oleh tenaga kesehatan sesuai dengan program puskesmas (metode lama). Pada akhir kegiatan pemberdayaan, para agen perubahan baik di daerah intervensi maupun kontrol diminta untuk membuat rencana tindak lanjut (RTL), dan dilakukan monitoring menggunakan matriks. Waktu pelaksanaan bulan Januari sampai Oktober tahun 2015.

Pengumpulan data kualititatif untuk mengeksplorasi proses pengendalian PTM 
yang dilakukan oleh para agen perubahan melalui observasi, wawancara mendalam, dan diskusi kelompok terarah (FGD). Pengumpulan data kuantitatif mengenai sosio-demografi, pengetahuan, sikap, dan perilaku faktor risiko PTM. Analisis data kuantitatif untuk melihat perubahan pengetahuan, sikap, dan perilaku positif dilakukan pre dan post test terhadap kelompok intervensi dan kontrol dalam pengendalian PTM menggunakan uji X2. Sedangkan analisis data kualitatif dilakukan dengan cara analisis tematik, matriks, dan konten analisis.

Kegiatan ini didukung oleh program CSR “Aqua Lestari”. Program CSR yang telah dilaksanakan adalah pembangunan klinik desa, program pemberdayaan masyarakat dalam menciptakan suplai air bersih dan penanaman tanaman untuk membantu ketersediaan air bersih di desa binaan perusahaan. Fakta tersebut membuat peneliti dan tim tertarik untuk mengoptimalisasi peran CSR yang telah ada, dengan memberikan program pemberdayaan masyarakat yang bersifat lebih intens terhadap pencegahan PTM. CSR "Aqua Lestari" berkontribusi dana pada saat agen perubahan melakukan tindak lanjut kegiatan dalam pengendalian PTM di masyarakat seperti menyiapkan konsumsi saat penyuluhan agen perubahan di desa, pembangunan poliklinik desa dan membagikan minuman saat car free day baik di Desa Nyangkowek maupun Desa Purwosari.

\section{HASIL}

\section{Karakteristik Agen Perubahan dan Proses Pemicuan}

Agen perubahan yang menjadi responden dalam penelitian ini sebanyak 40 orang yang terdiri dari masyarakat yang berpengaruh di wilayahnya dan berkomitmen mengikuti kegiatan sampai selesai. Mereka terdiri dari kader posyandu/ posbindu, tokoh agama, guru, LSM, ketua RW, dan aparat kelurahan. Desa Nyangkowek merupakan desa yang diberikan pemicuan (20 agen perubahan) dan Desa Purwosari sebagai desa kontrol (20 agen perubahan). Gambaran karakterisktik agen perubahan di Desa Nyangkowek maupun Desa Purwasari memperlihatkan pola yang hampir sama yaitu kelompok umur terbanyak di atas 40 tahun masing-masing sebanyak $60 \%$ dan $50 \%$. Jenis kelamin terbanyak adalah perempuan masing masing sebesar $75 \%$ dan $65 \%$ dan jenis pekerjaan yang terbanyak ibu rumah tangga masing masing sebesar $40 \%$ dan $45 \%$. Karakteristik agen perubahan dapat dilihat pada Tabel 1 berikut.

Kegiatan pemberdayaan di Desa Nyangkowek (daerah intervensi) dimulai dari membangun komitmen pada agen perubahan yang bertujuan untuk mempersiapkan agen perubahan supaya mengikuti seluruh tahapan proses pemicuan. Tahap pemicuan selanjutnya adalah identifikasi wilayah dimana agen perubahan melakukan identifikasi perilaku berisiko merokok, pola makan, dan aktifitas fisik yang ada di lingkungan desa agen perubahan serta kasus PTM khususnya stroke, hipertensi, DM, dan Jantung. Identifikasi wilayah dilakukan dengan berkeliling wilayah/desanya dan mengunjungi rumah penderita PTM. Proses ini didokumentasikan dengan handycam atau camera handphone milik agen perubahan. Hasil identifikasi wilayah tersebut merupakan bahan dalam pemicuan yang akan dilaksanakan. Proses pemicuan di balai Desa Nyangkowek selama 3 (tiga) hari oleh 20 agen perubahan. Pada awal kegiatan dilakukan pre test tentang pengetahuan dan sikap terkait perilaku berisiko merokok, pola makan, dan aktifitas fisik serta tentang pengetahuan penyakit hipertensi, stroke, DM, dan jantung. Tahap pemicuan dibagi menjadi 5 sesi sesuai tema yaitu pertama sesi pemicuan perilaku merokok, kedua sesi pemicuan pola makan tidak sehat, ketiga sesi pemicuan aktifitas fisik kurang, keempat sesi penyakit akibat merokok, pola makan tidak sehat dan kurangnya aktifitas fisik, kelima sesi perenungan, dan terakhir sesi penyusunan rencana tindak lanjut. Proses monitoring dan evaluasi terhadap aktivitas agen perubahan di lapangan dilakukan tiga kali.

Kegiatan di Desa Purwasari (daerah kontrol) terdiri dari: pre test dan post test, tahapan kegiatan diawali dengan komitmen dari agen perubahan, penyuluhan mengenai pengendalian faktor risiko PTM yang dilakukan oleh petugas puskesmas selama 3 hari. Pada akhir kegiatan dilanjutkan dengan proses monitoring dan evaluasi terhadap aktivitas yang dilakukan oleh agen perubahan.

Keberhasilan proses pemicuan pada agen perubahan dipaparkan berdasar pre dan post test, hasil pre dan post test menunjukkan peningkatan responden yang berpengetahuan baik, sikap yang positif, dan perilaku baik tentang faktor risiko PTM pada daerah intervensi dan daerah kontrol. Perubahan hasil pre dan post test agen perubahan dapat dilihat pada Tabel 2 berikut; 
Tabel 1. Karakteristik "Agen Perubahanee Desa Nyangkowek dan Desa Purwasari Kecamatan Cicurug, Kabupaten Sukabumi, 2015

\begin{tabular}{lcccc}
\hline \multirow{2}{*}{ Karakteristik } & \multicolumn{2}{c}{ Desa Nyangkowek } & Desa Purwasari (Desa Kontrol) \\
\cline { 2 - 4 } & $\mathbf{n}$ & $\mathbf{\%}$ & $\mathbf{n}$ & $\mathbf{\%}$ \\
\hline Umur (tahun) & 8 & & 10 & 50 \\
$<40$ & 12 & 40 & 10 & 50 \\
$>40$ & & 60 & & 35 \\
Jenis Kelamin & 5 & & 7 & 65 \\
Laki-laki & 15 & 25 & 13 & 15 \\
Perempuan & & & 15 \\
Pekerjaan & 5 & 25 & 3 & 15 \\
Aparat desa & 2 & 10 & 3 & 45 \\
Swasta/wiraswasta & 3 & 15 & 9 & 10 \\
Pensiunan & 8 & 40 & 2 & 100 \\
Ibu rumah tangga & 2 & 10 & 20 & \\
Guru PAUD & 20 & 100 & & \\
Total & & & & \\
\hline
\end{tabular}

Tabel 2. Skor Pre dan Post Test dari Pengetahuan, Sikap dan Perilaku tentang Faktor Risiko PTM dengan Kriteria Baik pada Daerah Intervensi dan Kontrol di Kecamatan Cicurug, Kabupaten Sukabumi, Tahun, 2015

\begin{tabular}{|c|c|c|c|c|c|}
\hline \multirow[t]{2}{*}{ Variabel } & \multicolumn{2}{|c|}{$\begin{array}{l}\text { Intervensi } \\
(\mathrm{n}=20)\end{array}$} & \multicolumn{2}{|c|}{$\begin{array}{c}\text { Kontrol } \\
(\mathrm{n}=20)\end{array}$} & \multirow[t]{2}{*}{$\mathrm{P}$} \\
\hline & $\mathrm{n}$ & $\%$ & $\mathrm{n}$ & $\%$ & \\
\hline \multicolumn{6}{|l|}{ Pengetahuan } \\
\hline Pre & 7 & 35 & 5 & 70 & 0.000 \\
\hline Post & 17 & 85 & 15 & 75 & \\
\hline \multicolumn{6}{|l|}{ Sikap } \\
\hline Pre & 7 & 35 & 11 & 55 & 0.003 \\
\hline Post & 18 & 90 & 15 & 75 & \\
\hline \multicolumn{6}{|l|}{ Prilaku } \\
\hline Pre & 10 & 50 & 7 & 35 & 0.008 \\
\hline Post & 19 & 95 & 13 & 65 & \\
\hline
\end{tabular}

Berdasarkan Tabel 2 dapat dilihat bahwa pada daerah intervensi menunjukkan selisih peningkatan pre - post untuk pengetahuan sebesar $50 \%$, sedangkan daerah kontrol hanya sebesar 5\%; sikap positif sebesar 55\%, daerah kontrol sebesar 20\%; perilaku yang benar sebesar $45 \%$, daerah kontrol sebesar $30 \%$. Uji statistik (X2) menunjukkan kemaknaan $\mathrm{p}<0,005$. Hal ini menunjukkan bahwa program pemicuan untuk pengendalian faktor risiko PTM berhasil.

\section{Monitoring dan Evaluasi Program Pemicuan}

Pelaksanaan program pemberdayaan masyarakat dilakukan monitoring dan evaluasi hasil capaian perilaku agen perubahan dalam menerapkan pengendalian PTM, hambatan, permasalahan dan solusi mengatasi masalah supaya program dapat berjalan maksimal. Hasil pemantauan di lapangan di daerah intervensi memperlihatkan; pengendalian perilaku berhenti merokok menunjukkan bahwa agen perubahan membuat stiker sendiri, kemudian menempelkan stiker tersebut di tempat fasilitas umum misalnya warung makan, pangkalan ojek, termasuk di rumah kost milik agen perubahan. Setelah kegiatan tersebut yang semula di rumahnya terdapat 3 (tiga) orang perokok sekarang berhenti merokok. Hal ini sebagaimana pernyataan agen perubahan B (Ketua RW):

"Merokok tidak ada keuntungannya, 
kami membuat stiker-stiker tentang Rumah Bebas Rokok, Saya sudah menempelkan stikerstiker yang dibuat disertai tulisan nama-nama penyakitnya dan cara mencegahnya”.

Agen perubahan bapak M (wiraswasta) mengatakan:

“ .... di rumah waktu itu ada tiga orang yang merokok sekarang sudah tidak lagi merokok. Kemudian di kosan saya juga biasanya anak kos habis pulang sekolah merokok, lalu saya tempelkan stiker dan akhirnya mereka pada kabur tidak kumpul lagi untuk merokok, meskipun ada satu anak yang akhirnya keluar dari kosan saya....".

Responden Agen perubahan N (Ibu RI) menyampaikan:

"Profesi saya jualan warung sembako, penyuluhan saya lakukan terhadap para pembeli rokok dan selalu menghimbau kepara para pembeli agar mengurangi rokoknya...".

\section{Perilaku beri}

iko merokok dianggap sebagai budaya masyarakat di wilayah ini, sehingga perlu upaya lebih agen perubahan untuk menyampaikan bahaya merokok. Usaha yang telah dilakukan dalam pengendalian merokok perlu diberi apresiasi bahwa mereka tetap melaksanakan kegiatan penyuluhan, berhenti merokok dan membuat leaflet/stiker. Kegiatan ini mendapat dukungan dari kecamatan dan CSR dari beberapa perusahan di Kecamatan Cicurug.

Hasil aksi Perilaku pola makan para agen perubahan, disampaikan melalui pernyataan agen perubahan bu A (guru PAUD) :

" Pola makan kita ada perubahan, biasanya saya senang menggoreng dan menumis, sekarang saya rebus gambas (labu siem), kacang panjang, buncis, dan tahu paling di pepes. ".

Pernyataan agen perubahan Z (ibu Rumah Iangga):

“...kalau dulu suka beli gorengan, kalau sekarang mau pisang ya saya rebus, mau ubi ya saya rebus, kalau sayuran juga minyak-minyak dikurangi..."

Aksi lain agen perubahan adalah memberikan penyuluhan terhadap kader posyandu mengenai makanan sehat. Kegiatan memberikan penyuluhan terhadap ibu-ibu yang sedang menunggu anak-anaknya di PAUD Cendrawasih Jl. Ciutara Desa Nyangkowek RI
01/01 Kecamatan Cicurug, Kabupaten Sukabumi. Kegiatan pemicuan kurangnya aktifitas fisik, masyarakat masih berpendapat bahwa melakukan aktititas kerja sehari-hari berarti sudah melakukan aktifitas fisik, karena kalau sengaja melakukan aktivitas fisik yang mengarah pada kebugaran tidak dilakukan secara teratur karena keterbatasan waktu. Hasil aksi aktifitas fisik dapat dilihat dari pernyataan agen perubahan $M$ sebagai penggiat senam:

"Kita menggiatkan senam sehat pada car free day, sampai senam ibu-ibu di pasar pagi hari Minggu...".

Agen Perubahan memberi penyuluhan kepada anak-anak PAUD dan orang tuanya sekitar 25 orang dengan materi mengenai cara hidup sehat, tidak merokok, pola makan yang sehat dan aktivitas fisik serta penyakit PTM. Selama mengikuti kegiatan orang tua murid sangat antusias dan bertanya mengenai kebiasaan hidup yang baik dan sehat. Kegiatan ini dilakukan setiap bulan dengan materi yang bergantian sesuai rencana RTL dari agen perubahan serta monitoring dan evaluasi. Selanjutnya ada kegiatan di Posyandu BKM Amanah (yang didirikan dan disponsori oleh PNPM Mandiri melalui CSR Kabupaten Sukabumi). Pelaksanaan kegiatan penyuluhan yang dilakukan agen perubahan kepada sekitar 20 ibu balita dengan materi pola hidup sehat, pola makan dengan gizi seimbang, larangan tidak merokok, aktivitas fisik, ancaman bahaya PTM (gula, darah tinggi, jantung, dan stroke). Orang tua balita memberikan tanggapan serius dan penuh perhatian, sepertinya apa-apa yang diterangkan oleh para kader di lingkungan sekitar mereka.

Kegiatan yang sudah dilakukan agen perubahan daerah kontrol (Desa Purwosari) adalah secara kelompok yaitu pada acara PKK, senam pagi, pengajian, dan penyuluhan langsung secara perorangan. Kegiatan di PKK Muray, agen perubahan memberikan pencerahan yang dihadiri anggota PKK yang hadir sebanyak 15 orang dengan materi mengenai hipertensi, dampak konsumsi makanan yang tidak teratur dengan menu tidak seimbang, akibat konsumsi makanan dengan zat-zat pengawet (pemanis), aktifitas fisik yang tidak teratur, bahaya merokok terutama bagi anak-anak. Kegiatan tersebut diselenggarakan di Kampung Caringin Lapang RT/RW 02/06, Desa Purwosari. 
Program CSR PT Aqua dan perusahaan lainnya di Kecamatan Cicurug dilakukan melalui kemitraan dengan masyarakat, pemerintah daerah dan para pemangku kepentingan yang lain. Kegiatan yang telah dilakukan antara lain program pelestarian lingkungan, pemberdayaan masyarakat, perilaku kesehatan, pendidikan, dan peningkatan ekonomi. Program pemberdayaan masyarakat dalam bidang kesehatan adalah penyediaan air bersih melalui pemasangan pompa air dan penyuluhan kesehatan mengenai pentingnya hidup bersih serta sehat. ${ }^{11}$ Dukungan CSR "Aqua Lestari" para program pemberdayaan masyarakat dalam pengendalian faktor risiko PTM adalah mendukung kegiatan penyuluhan perilaku hidup sehat dan pengendalian faktor risiko PTM yang dilakukan oleh agen perubahan, pembangunan poliklinik desa serta kegiatan gerak jalan sehat melalui car free day. Setelah kegiatan tersebut diterapkan, warga mengetahui dan paham untuk mengendalikan faktor risiko PTM melalui mengurangi merokok, perilaku pola makan yang sehat, dan peningkatan aktifitas fisik. Program CSR "Aqua Lestari" akan berkelanjutan dimana setiap program CSR yang telah dilaksanakan dipantau perkembangan dan tingkat keberhasilannya, kemudian program tersebut dilakukan secara kontinu dan berkesinambungan sehingga tidak hanya sekedar membahagiakan masyarakat secara instan dan sekejap, namun menjadi kebiasaan. Kepala desa akan mengoordinir CSR "Aqua Lestari” untuk mendukung keberlangsungan program serta meminta komitmen dari agen perubahan untuk dapat melakukan program pengendalian PTM secara berkelanjutan.

\section{PEMBAHASAN}

Setiap manusia dan masyarakat memiliki potensi yang dapat dikembangkan, sehingga pemberdayaan masyarakat adalah upaya untuk membangun yaitu dengan mendorong, memberikan motivasi dan membangkitkan kesadaran akan potensi yang dimiliki serta untuk mengembangkannya. Tahapan dalam melakukan pemberdayaan masyarakat meliputi pengembangan (enabling), memperkuat (empowering) dan memberdayakan (melindungi). ${ }^{12}$ Pemberdayaan juga dapat dilihat pada tingkat yang berbeda yaitu individu, organisasi atau komunitas. Tingkat ini terkait erat dalam komunitas yang diberdayakan, adanya organisasi yang diberdayakan, dan organisasi yang diberdayakan bergantung pada tingkat pemberdayaan anggotanya. ${ }^{13}$ Kegiatan pemberdayaan masyarakat harus dilaksanakan secara integratif dengan memperhatikan peningkatan kapasitas masyarakat sehingga kegiatannya dapat dilaksanakan secara

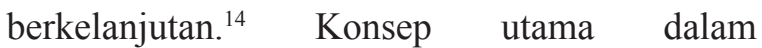
pemberdayaan masyarakat adalah untuk memobilisasi komunitas lokal untuk mengatasi kebutuhan kesehatan dan sosial mereka dan bekerja secara inter-sektoral untuk memecahkan masalah lokal. ${ }^{15}$

Pemberdayaan masyarakat dalam hal pengendalian PTM di Desa Nyangkowek dan Desa Purwasari Kecamatan Cicurug menunjukkan keberhasilan yang tidak terlepas dari pemberian pemicuan melalui pendekatan dengan masyarakat. Temuan ini sesuai dengan pendapat yang menyatakan bahwa pemberdayaan masyarakat diperlukan pendekatan utama yaitu masyarakat tidak dijadikan sebagai objek melainkan subjek dari berbagai upaya pembangunan melalui pendekatan-pendekatan sebagai upaya pemberdayaan harus terarah, program pemberdayaan harus langsung mengikutsertakan atau bahkan dilaksanakan oleh masyarakat yang menjadi sasaran, dan menggunakan pendekatan kelompok. ${ }^{16}$ Pemberdayaan atau intervensi berbasis masyarakat di bidang kesehatan dapat melibatkan komunitas dalam perbedaan peran seperti masyarakat sebagai pengaturan untuk intervensi, masyarakat sebagai target berubah, masyarakat sebagai agen dengan kapasitas perkembangan, dan masyarakat sebagai sumber daya dengan tingkat kepemilikan dan partisipasi yang tinggi. ${ }^{17}$

Partisipasi masyarakat sebagai pemicu kemandirian dan proses pemberdayaan adalah komponen yang sangat penting. Proses tersebut dilakukan secara akumulatif sehingga semakin banyak keterampilan, atau semakin tinggi kompetensi yang dimiliki seseorang maka semakin tinggi kemampuannya berpartisipasi. ${ }^{8,18,19}$ Pemberdayaan masyarakat dilakukan dengan diberikannya pemicuan P2TMBM yang merupakan salah satu media alternatif baru yang dapat digunakan untuk meningkatkan pengetahuan, sikap dan perilaku. Penelitian ini menghasilkan pengetahuan 
responden meningkat setelah diberi pemicuan P2TMBM selama 2 minggu. Pemicuan tersebut berkaitan dengan Teori Kerucut Pengalaman oleh Edgar Dale bahwa setelah 2 minggu kita cenderung lebih mengingat $10 \%$ dari apa yang kita baca, 20\% dari apa yang kita dengar, 30\% dari apa yang kita lihat, 50\% dari apa yang kita dengar dan lihat, 70\% dari apa yang kita katakan dan $90 \%$ dari apa yang kita katakan dan kita lakukan. ${ }^{20}$

Penelitian ini berpengaruh besar terhadap peningkatan sikap yaitu faktor pengalaman pribadi yang akan lebih mudah membentuk sikap jika kejadian yang dialami seseorang terjadi dalam situasi yang melibatkan faktor emosional. Hal tersebut dapat dilihat dari sikap yang dipilih oleh responden terhadap beberapa pernyataan mengenai kejadian sehari-hari sesuai dengan materi proses pemicuan yang di berikan. Dengan diberi pemicuan P2TMBM maka responden mendapatkan suatu pengalaman tersendiri yang dapat menguatkan sikap mereka untuk berubah. ${ }^{21}$ Perubahan perilaku mengenai PTM pada agen perubahan dapat dilihat dengan berusaha merubah diri sendiri untuk hidup sehat, berhenti merokok dan merubah pola makan menjadi seimbang dengan kesadaran diri sendiri tanpa paksaan dari orang lain serta memberikan penyuluhan kepada orang lain. Hasil penelitian lain menyebutkan bahwa perilaku kesehatan yang diadopsi akan mengubah risiko penyakit yang diderita seperti merokok, diet tidak sehat, dan aktivitas fisik yang kurang dapat meningkatkan risiko PTM. Faktorfaktor risiko ini dapat memiliki efek langsung pada kesehatan atau dapat mempengaruhi perkembangan tekanan darah tinggi, peningkatan glukosa darah dan kadar kolesterol, yang kemudian akan meningkatkan risiko penyakit kronis seperti penyakit kardiovaskular dan diabetes. $^{22}$

Tindakan perubahan perilaku yang dilakukan oleh agen perubahan sesuai dengan konsep perilaku yang merupakan tindakan aktif atau beraktivitas dari manusia itu sendiri dan dapat diamati langsung atau tidak dapat diamati oleh pihak luar. ${ }^{23}$ WHO mengungkapkan bahwa seseorang berperilaku tertentu disebabkan oleh pemikiran dan perasaan dalam bentuk pengetahuan, persepsi, sikap, kepercayaan, dan penilaian-penilaian seseorang terhadap objek. Dalam hal ini, dengan pemberian pemicuan
P2TMBM maka pengetahuan dan sikap akan bertambah sehingga perilaku juga akan menjadi lebih baik. ${ }^{23}$ Dalam rangka keberlanjutan program dimana perubahan perilaku yang memerlukan waktu yang lama dibutuhkan komitmen dari berbagai pihak termasuk program CSR "Aqua lestari”..Program CSR "Aqua Lestari" memiliki pengaruh baik secara simultan maupun parsial terhadap Pemberdayaan Masyarakat. CSR didefinisikan sebagai tanggungjawab perusahaan kepada para pemangku kepentingan (stakeholders) untuk berlaku etis, meminimalkan dampak negative dan memaksimalkan dampak positif yang mencakup aspek ekonomi, sosial dan lingkungan (triple bottom line). ${ }^{24}$ Keberadaan 120 perusahaan besar dan kecil di lingkungan Kecamatan Cicurug memberikan investasi sosial yang bermanfaat bagi lingkungan di sekitarnya. Fokus utama program CSR yang dilakukan antara lain oleh "Aqua Lestari" selaku perusahaan terkait bekerjasama dengan perangkat desa setempat untuk menjalankan program-program CSR agar dapat meningkatkan pemberdayaan masyarakat di sekitar wilayahnya baik melalui pendidikan, kesehatan maupun lingkungan. Program CSR di Desa Nyangkowek dan Desa Purwasari mampu memberdayakan masyarakat dalam pengendalian PTM melalui dukungan dana untuk kegiatan dan penyuluhan. Perangkat desa dengan CSR dengan menanggung biaya sarana dan prasarana kegiatan pengendalian penyakit tidak menular oleh para agen perubahan.

Seiring dengan perkembangan isu lingkungan global, konsep, dan aplikasi CSR semakin berkembang. Berdasarkan penelitian lain menunjukkan bahwa semua variabel yang digunakan yaitu Corporate Social Responsibility Goal, Corporate Social Issue, dan Corporate Relation. Program secara signifikan memiliki pengaruh positif terhadap peningkatan kesejahteraan hidup masyarakat, umumnya di Indonesia. ${ }^{25} \mathrm{CSR}$ tidak semata menjadi kewajiban sosial perusahaan, namun juga dikaitkan sebagai konsep pengembangan yang berkelanjutan (sustainable development). Program CSR bidang kesehatan antara lain pelestarian lingkungan dan air sungai, pemberdayaan masyarakat, program air bersih dan sehat, peningkatan status kesehatan melalui promotif dan preventif, bantuan sosial, pendidikan, dan peningkatan ekonomi. ${ }^{26}$

Hal ini sesuai dengan penelitian 
pemberdayaan masyarakat yang dilakukan Yuniarti $\mathrm{dkk},{ }^{27}$ yaitu pemberian training kesehatan kepada masyarakat Desa Pacarkeling dalam meningkatkan perilaku hidup sehat dan lingkungan yang bersih, penggunaan MCK yang tepat dan sehat, penyediaan bantuan air bersih. Program CSR yang diberikan kepada masyarakat dapat berkontribusi optimal di pihak masyarakat dan perusahaan sebesar 95\% dan memberdayakan masyarakat membangun ekonomi mandiri yang berkesinambungan. Pelaksanaan program-program CSR PT. Batamindo Investment Cakrawala (BIC) mampu meningkatkan kemandirian masyarakat dalam bidang pendidikan dan kesehatan dalam aktivitas kesehatan. ${ }^{24,25}$ Sebagaimana penelitian lain menyatakan bahwa program CSR pada PT PLN berhasil memberdayakan masyarakat melalui perubahan perilaku dalam hal ekonomi, lingkungan dan perilaku kesehatan. ${ }^{26}$

\section{KESIMPULAN}

Pemberdayaan masyarakat melalui program pemicuan P2TMBM berhasil secara signifikan ( $p<0,005)$ memperbaiki pengetahuan, sikap dan perilaku agen Perubahan dalam pengendalian faktor risiko PTM, sehingga mereka bisa memberikan informasi kesehatan sekaligus menggerakan masyarakat untuk mau dan mampu dalam melakukan pengendalian faktor risiko PTM, metode ini dapat di aplikasikan ke wilayah lain serta untuk program kesehatan yang lainnya. Program CSR "Aqua Lestari" di Kecamatan Cicurug Kabupaten Sukabumi mampu menjaga keberlangsungan pemberdayaan masyarakat dalam pengendalian faktor risiko PTM.

\section{SARAN}

Dengan meningkatnya faktor risiko PTM di kabupaten Sukabumi, diusulkan pada Dinas Kesehatan Kabupaten Sukabumi dan Puskesmas kecamatan Cicurug, untuk meningatkan monitoring dan evaluasi dalam menjaga keberlangsungan program pemberdayaan masyarakat yang sudah ada, serta pengembangan model pemicuan P2TMBM di desa lainnya. Diharapkan Program CSR "Aqua Lestari" agar terus konsisten mendukung program pemberdayaan masyarakat pengendalian PTM yang ada di Kecamatan Cicurug.

\section{UCAPAN TERIMA KASIH}

Penulis mengucapkan terima kasih kepada drg. Agus Suprapto, M.Kes, sebagai Kepala Puslitbang Humaniora, Kebijakan Kesehatan dan Pemberdayaan Masyarakat yang telah memberikan dukungan dalam penelitian. Terima kasih juga kami sampaikan kepada Kepala Dinas Kesehatan Kabupaten Sukabumi, Kepala Puskesmas Cicurug, Kepala Desa Nyangkowek, dan Kepala Desa Purwosari yang telah membantu dalam pelaksanaan penelitian ini serta memberikan masukan dan tanggapan yang memperkaya temuan penelitian ini.

\section{DAFTAR PUSTAKA}

1. Kementerian Kesehatan RI. Litbangkes dalam Angka 2017. Jakarta: Lembaga Penerbit Badan Penelitian dan Pengembangan Kesehatan; 2017.

2. Kementerian Kesehatan RI. Riset Kesehatan Dasar 2007. Jakarta: Badan Penelitian dan Pengembangan kesehatan Kesehatan; 2007.

3. Kementerian Kesehatan RI. Riset Kesehatan Dasar 2013. Jakarta: Badan Penelitian dan Pengembangan Kesehatan; 2013.

4. Dinas Kesehatan Kabupaten Sukabumi. Profil dinas kesehatan Kabupaten Sukabumi. Sukabumi: Dinas Kesehatan Kabupaten Sukabumi; 2015.

5. Undang-Undang No.36 Tahun 2009 tentang Kesehatan; 2009

6. Prasojo E. People and society empowerment: perspektif membangun partisipasi publik. Jurnal Ilmiah Administrasi Publik. 2004;4(2):10-24.

7. Departemen Kesehatan. Pemberdayaan masyarakat. Jakarta: Departemen Kesehatan; 1999.

8. Wahyudi I, Azheri B. Corporate social responsibility. Malang: Setara Press; 2008.

9. Ardianto E, Machfudz DM. Efek kedermawanan pebisnis dan CSR berlilipatlipat. Jakarta: Elex Media Komputindo; 2011.

10. Rachmawati T. Pemicuan pencegahan penyakit tidak menular berbasis masyarakat di Indonesia (Laporan Penelitian). Surabaya: Pusat Humaniora, Kebijakan Kesehatan dan Pemberdayaan Masyarakat; 2015.

11. Rachmawati T. Pedoman pemicuan pencegahan penyakit tidak menular berbasis masyarakat. Surabaya: Pusat Humaniora, Kebijakan Kesehatan dan Pemberdayaan Masyarakat; 2014. 
12. Kecamatan Cicurug. Laporan kegiatan tahunan kecamatan Cicurug Kabupaten Sukabumi, Jawa Barat; 2015.

13. Kartasasmita G. Power dan empowerment: sebuahtelaahmengenaikonseppemberdayaan masyarakat. Pidato Kebudayaan Ketua Bapennas pada peringatan hari jadi ke 28 Pusat Kesenian Jakarta-TIM. Jakarta 19 November 1996.

14. Arif B. Corporate social responsibility alternatif bagi pembangunan Indonesia. Jakarta: Indonesia Center for Sustainable Development (ICSD); 2008

15. Kartasasmita G. Pemberdayaan masyarakat: konsep pembangunan yang berakar pada masyarakat. Pidato ketua Bapennas pada Sarasehan DPD Golkar Tk.I Jawa Timur. Surabaya 14 Maret 1997.

16. Pranaka AMW, Moeljanto V. Pemberdayaan (empowerment) Dalam Prijono OS dan Pranaka AMW. Pemberdayaan: konesp, kebijakan dan implementasi, Jakarta: CSIS;2010

17. Hutomo MY. Pemberdayaan masyarakat dalam bidang ekonomi; tinjauan teoritik dan implementasi. 2000 [cited 2015 Januari 11]. Available from http://www.bappenas.go.id/ data-dan-informasiutama/makalah/artikelmajalah-perencanaan/edisi-20-tahun2000/ pemberdayaan masyarakat-dalam-bidangekonomi---oleh-mardi-yatmo- hutomo/

18. Dale E. The cone of experience "from audiovisual methodes in teaching, 1 st Edition. America; 2000

19. Qomaruddin B. Pengembangan indikator pemberdayaan dan cara pengukurannya untuk menentukan mingkat keberdayaan Desa Siaga di Kabupaten Lumajang. Ringkasan
Disertasi, Fakultas Kesehatan Masyarakat, Program Doktor Ilmu Kesehatan Masyarakat. Depok; Januari 2013.

20. Notoadmojo S. Ilmu perilaku kesehatan. Jakarta: Rineka Cipta; 2013

21. 21. Wibisono Y. Membedah konsep dan aplikasi CSR (Corporate Social Responsibility). Jakarta: PT Gamedia; 2007

22. Setyaningrum DA. Pengaruh implementasi corporate social responsibility terhadaph kesejahteraan hidup masyarakat (Studi Kasus pada PT. Apac Inti Corpora, Bawen). Semarang : UNDIP; 2011

23. Irawan EP. Program CSR berbasis pemberdayaan masyarakat pada PT PLN. Jurnal Tesis tidak diterbitkan. Universitas Padjadjaran; 2011

24. Wahyuningrum Y, Noor I, WachidA.Pengaruh program corporate social responsibility terhadap peningkatan pemberdayaan masyarakat. (Studi pada Implementasi CSR PT. Amerta Indah Otsuka Desa Pacarkeling Kecamatan Kejayan Kabupaten Pasuruan). Jurnal Administrasi Publik (JAP), Vol.1 No.5, Hal 109-115.tahun 2014

25. Pranoto A, Yusuf D. Program CSR berbasis pemberdayaan masyarakat menuju kemandirian ekonomi pasca tambang di Desa Sarijaya. Jurnal Ilmu Sosial dan Ilmu Politik. Juli 2014;18(1):39-50.

26. Mapisangka A. Implenetasi CSR PT BIC terhadap kesejahteraan hidup masyarakat. JESP. 2009; 1 .

27. Irawan EP. Program CSR berbasis pemberdayaan masyarakat pada PT PLN. Jurnal Tesis tidak diterbitkan. Universitas Padjadjaran; 2011 